\title{
INTENSIVE DIFFERENT STOCKING DENSITIES OF NILE TILAPIA, Oreochromis niloticus AND CHECKED SILVER CARP, Hypophthalmichthys molitrix UNDER MONO-OR POLYCULTURE SYSTEMS IN FLOATING NET CAGES REARING IN MANZALA LAKE, Egypt \\ Khalil, F.F.; F. H. Farrag*; A. A. El Shebly ${ }^{*}$ and A. M. Behery* \\ Animal Production Dept., Fac. Agric., Mans. Univ., Mans., Egypt. \\ "Fish culture Lab., National Institute of Oceanography and Fisheries, Egypt.
}

\begin{abstract}
This experiment was designed in order to study the effect of intensive rearing of mono-sex Nile tilapia and Silver carp under mono-or polyculture systems at different stocking densities in floating net cages. Fish were male mono-sex Nile tilapia with an average initial body weight $(19.30 \mathrm{~g})$ and Silver carp with an average initial body weight $(73.6 \mathrm{~g})$. The experimental fish were adapted for one week in floating netcages and then distributed randomly into five experimental cages. The first cage was stocked with Nile tilapia, at a rate of $30 \mathrm{fish} / \mathrm{m}^{3}$, while the $2^{\text {nd }}$, the $3^{\text {rd }}$ and $4^{\text {th }}$ cages were stocked with different densities of Nile tilapia with Silver carp, at a rate of 30 fish $/ \mathrm{m}^{3}$ and the fifth cage was stocked with Silver carp only at a rate of $6 \mathrm{fish} / \mathrm{m}^{3}$. All fish groups were feed the same artificial pelleted diet (except $5^{\text {th }}$ group fed natural water food). The diets were contained of $26.58 \%$ crude protein and gross energy 410.35 $\mathrm{Kcal} / 100 \mathrm{~g} \mathrm{DM}$, and offered twice daily (at 8.30 a.m. and 15.00 p.m.). The feeding rate represented $4 \%$ of mass body weight during all experimental periods.

The main results showed that the best treatment was the monoculture of monosex Nile tilapia (30 fish $\left./ \mathrm{m}^{3}\right)$, then followed by the polyculture $(88 \%$ Nile tilapia) and $(12 \%$ Silver carp) in most of the examined traits as well as in the economic efficiency. The obtained results showed also that the intensive monoculture systems of silver carp had the lowest economic efficiency related to the only natural food in water only.

The present obtained results lead to the importance using the balanced pelleted complete diet for feeding tilapia fish especially under intensive cultured (monoculture); as well as, depending of green water for fed Silver carp in intensive monoculture. Also, showed the superiority of stocking densities in polyculture system were $88 \%$ and $12 \%$ for Nile tilapia and Silver carp, respectively As well as from environmentally point of view, it could be concluded that the controlling on different source of water pollution in Manazala Lake are very important to get high quality and safety fish production.
\end{abstract}

\section{INTRODUCTION}

Egypt has various inland resources, include the Nile River with many irrigation canals, six northern coastal lagoons (Mariut, Edku, Borollus, Manzala, Port Fouad and Bardawil). All of these lakes, with the exception of Lake Mariut, are directly connected to the Mediterranean Sea (El-Ganainy, 2006).

In Egypt, most of the aquaculture production derived from tilapia either from semi-intensive fish farms in earthen ponds or integrated intensive fish farms and cages (GAFRD, 2006). Thus, tilapia production in Egypt now takes 
the $2^{\text {nd }}$ position after China in the world production, as well as, the 1 st in Africa and Middle East. On the other hand, Silver carp is plentiful and a nutritious source of protein, the potential value of this fish has not been fully utilized in the Egyptian market. It is well known that the native of Silver carp were China, is filter feeding omnivores. The fish has been widely introduced throughout the old for aquaculture and it is contributing $22 \%$ ( $>3$ million tons) of world carp aquaculture production (FAO, 2005).

El-Sayed (2013) now a day's reported that semi-intensive tilapia culture has been adopted in various parts of the world, either in monoculture or polyculture systems. In the same time, semi-intensive tilapia culture with other herbivorous / omnivorous fish such, as (common carp, Silver carp and grass carp) were found. It is important to know the role of the floating cages in the total Egyptian fish production since improving and out spreading of aquaculture among private sector which led to developing and intensification the fish culture supply in the market and reduced its price (Aldwaney, 2002 \& GAFRD, 2008). In addition a lot of results, Ellis et al., (2002) and El-Sayed (2006) shown that stocking density is a key factor in determining the productivity and profitability of commercial fish farms.

Therefore, the aim of this study was to investigate the effects of both polyculture and monoculture between tilapia and carp fish at different stocking density under rearing cages system at Manzala Lake, Egypt, on productive performance and economic efficiency.

\section{MATERIALS AND METHODS}

The present study was carried out as a part of the project of fish cages culture of young farmers in Manzala Lake (Raswah Lisa Al-Gamaliah), Dakahlia Governorate, Egypt. Five floating net cages $(10 \mathrm{~m}$ length $X 10 \mathrm{~m}$ Width $X 2 \mathrm{~m}$ Depth $)=\left(200 \mathrm{~m}^{3}\right)$. This study was extended 124 days (four months) from 15 July till 15 November, 2013.

Fish species were male mono-sex Nile tilapia, Oreochromis niloticus with an average initial body weight (19.30 $\pm 0.5 \mathrm{~g})$ and Silver carp, Hypophthalmichthys molitrix with an average initial body weight $(73.67 \pm 0.5$ g) were used in this experiment. Mono-sex of Nile tilapia was purchased from a private Manzala hatchery, Egypt. While, Silver carp were purchased from a private Fish Farm of Yoseph Asal at the same district (Raswah Lisa AlGamaliah, Egypt).

The experimental fish were adapted for one week in floating net-cages. The fish were weighed and then distributed randomly into five experimental groups as illustrated and design in Table (1). The first cage was stocked with Nile tilapia, only, at a rate of 30 fish $/ \mathrm{m}^{3}$, the second, the third and fourth cages were stocked with different densities of Nile tilapia with Silver carp, at a rate of $30 \mathrm{fish} / \mathrm{m}^{3}$ and the fifth cage was stocked with Silver carp only at a rate of 6 fish $/ \mathrm{m}^{3}$. 
Table (1): Illustrated the design of experimental fishes:

\begin{tabular}{|c|c|c|c|c|c|c|c|}
\hline $\begin{array}{c}\text { Cage } \\
\text { Number }\end{array}$ & $\begin{array}{c}\text { Number } \\
\text { of Nile } \\
\text { tilapia }\end{array}$ & $\begin{array}{c}\text { Initial } \\
\text { weight (g) }\end{array}$ & $\begin{array}{c}\text { Biomass } \\
\mathbf{( k g )}\end{array}$ & $\begin{array}{c}\text { Number } \\
\text { of Silver } \\
\text { carp }\end{array}$ & $\begin{array}{c}\text { Initial } \\
\text { weight (g) }\end{array}$ & $\begin{array}{c}\text { Biomass } \\
\mathbf{( k g )}\end{array}$ & $\begin{array}{c}\text { Total } \\
\text { biomass of } \\
\text { cage (kg) }\end{array}$ \\
\hline 1 & 6000 & $\begin{array}{c}19.30 \pm \\
0.5 \mathrm{~g}\end{array}$ & 115.80 & - & - & - & 115.80 \\
\hline 2 & 5760 & $\begin{array}{c}19.30 \pm \\
0.5 \mathrm{~g}\end{array}$ & 111.10 & $240(4 \%)$ & $\begin{array}{c}73.67 \pm \\
0.5 \mathrm{~g}\end{array}$ & 17.70 & 128.80 \\
\hline 3 & 5520 & $\begin{array}{c}19.30 \pm \\
0.5 \mathrm{~g}\end{array}$ & 106.50 & $480(8 \%)$ & $\begin{array}{c}73.67 \pm \\
0.5 \mathrm{~g}\end{array}$ & 35.40 & 141.90 \\
\hline 4 & 5280 & $\begin{array}{c}19.30 \pm \\
0.5 \mathrm{~g}\end{array}$ & 102.00 & $720(12 \%)$ & $\begin{array}{c}73.67 \pm \\
0.5 \mathrm{~g}\end{array}$ & 53.00 & 155.00 \\
\hline 5 & & - & & 1200 & $\begin{array}{c}73.67 \pm \\
0.5 \mathrm{~g}\end{array}$ & 88.40 & 88.40 \\
\hline
\end{tabular}

All fish groups were fed the same artificial pelleted diet contains $26.58 \%$ crude protein and gross energy $410.35 \mathrm{Kcal} / 100 \mathrm{~g} \mathrm{DM}$, (purchased from Abu Abbas Feed Factory belonging to, the industrial zone El- Asafra, AlMatariah, Dakahliah governorate, Egypt), except group number five fed natural feed. The diet was offered twice daily at 8.30 a.m. and 15.00 p.m. The diets were adjusted biweekly on the basis of the actual average biomass of the fish in each cage at $4 \%$ rate (from the beginning to the end during all experimental periods). The Chemical analysis of experimental diet was given in Table (2).

Table (2): The Chemical analysis of experimental diet:

\begin{tabular}{|l|c|}
\hline Nutrient Composition & Average \\
\hline Total moisture \% & 9.50 \\
\hline Dry matter (DM \%) & 90.50 \\
\hline Nutrient composition (\% on dry matter basis) \\
\hline Crude protein (CP) & 26.58 \\
\hline Ether extract (EE) & 6.14 \\
\hline Crude fiber & 8.33 \\
\hline Ash & 9.67 \\
\hline Total carbohydrates & 49.28 \\
\hline${ }^{*}$ Gross energy (GE) & 410.35 \\
\hline${ }^{*}$ Protein/energy (P/E) ratio & 64.76 \\
\hline${ }^{*}$ GE (Kcal/100g DM) $=$ CP x 5.64 + EE x 9.44 + Carbohydrates x 4.11 calculated according \\
to (Macdonald et al., 1973). \\
**P/E ratio (mg protein/Kcal gross energy) = CP/GE x 1000.
\end{tabular}

Water quality parameters were measured in all experimental cages at the start and during the experiment biweekly as, water temperature by using a thermometer, dissolved oxygen concentration was determined by using the Winkler method (APHA, 1971). Total ammonia and $\mathrm{pH}$ values of water was measured by direct Nesslerization methods using a CHEMETS $^{\circledR}$ test kits (CHEMETRICS, INC, USA) according to APHA (1992).

Body weight of individual fish sample from each species was weighed biweekly to determine feed quantity and to calculate growth performance and feed utilization according to Abdelhamid (2003) as the following: average 
weight gain (g / fish) (AWG), average daily gain, (g / fish / day) (ADG), relative growth rate (RGR \%), specific growth rate (SGR, \% / day), feed conversion ratio (FCR), protein efficiency ratio (PER), protein productive value (PPV \%) and energy utilization (EU \%) were determine as well calculated.

At the end of the experiment, fish samples from each cage were taken and kept in frozen until chemical analysis. The chemical analysis of the experimental diet and the whole body fish was carried out according to the AOAC (2000), at the start and the end of the experimental period. The chemical analysis carried out at the Department of Animal Production, fish laboratory, Faculty of Agriculture, Mansoura University, Egypt.

At the end of the present study economic efficiency parameters (total outputs, total costs, net return and economic efficiency) of each experimental site cage were calculated as shown in Table (8).

The obtained data were statistically analyzed by one way using, but water quality SAS (2006) procedures for personal computer. When F-test was positive, least significant difference by Duncan (1955) was calculated for the comparison among means for all cages in the experiments.

\section{RESULTS AND DISCUSSION}

On the basis of the characteristics of Manzala area, Egypt, in evaluating and regulating their suitability for fish rearing, it was found that all parameters revealed to be within the permissible levels for optimum fish growth. Therefore the mean values of water quality parameters in cages were recorded as shown in (Table 3 ). The recorded ranges were $21.5-28{ }^{\circ} \mathrm{C}$ water temperature, 2.15-3.45 $\mathrm{mg} / \mathrm{L}$ dissolved oxygen (DO), 7-8 pH and low total ammonia $\left(\mathrm{NH}_{3}\right)$ 0.001- $0.03 \mathrm{mg} / \mathrm{L}$ during all experimental periods. It could be noticed that the dissolved oxygen was very low may be because of the proliferation of aquatic plants, the lack of speed of the water renewal and increase the number of cages in Manzala Lake.

From the data in Table (3), it could be noticed that the differences in the means of temperature, dissolved oxygen, $\mathrm{pH}$ and $\mathrm{NH}_{3}$ were not significantly different among the cages or months $(P>0.05)$. The present results are in agreement with those of Degefu et al., (2011). They found that physical parameters showed no significantly different between the cages. The exceptions were $\mathrm{DO}$ and $\mathrm{NH}_{3}$, which were lower and higher in the cages, respectively.

Growth performances of Nile tilapia in the different experimental groups were given in (Table 4). Means of initial fish weights were the same among stocking density treatments $(19.30 \mathrm{~g})$. In the other side, the Nile tilapia growth represented by the averages final weight, weight gain, ADG, RGR and SGR (Table 4 ) were significantly affected by stocking density $(P \leq 0.05)$. The results showed that growth was positively affected by stocking density.

Similarly different experiment results on the effect of stocking density conducted on different tilapia fish sizes including fry and juveniles (khattab et al., 2004 and Abdelhamid et al., 2007), sub- adults (Bakeer et al., 2007) and large tilapia (Diana et al., 2004). Furthermore, Ellis et al., (2002) reported that 
stocking density is a key factor in determining the productivity and profitability of the commercial fish farms were obtained.

(Table 3) Mean of water samples parameters in cage's site during of the experimental periods:

\begin{tabular}{|l|c|c|c|c|}
\hline $\begin{array}{l}\text { Treatment/ } \\
\text { Measurement }\end{array}$ & Temperature ${ }^{\circ} \mathbf{C}$ & DO $\mathbf{~ m g / L ~}$ & $\begin{array}{c}\mathbf{p H ~} \mathbf{~ m} / \mathbf{L} \\
\mathbf{C a C O}_{3}\end{array}$ & $\mathbf{N H}_{\mathbf{3}} \mathbf{~ m g} / \mathbf{L}$ \\
\hline \multicolumn{5}{|c|}{ Cages } \\
\hline T1 & 25.5 & 2.497 & 7.200 & 0.0018 \\
\hline T2 & 25.5 & 2.808 & 7.200 & 0.0018 \\
\hline T3 & 25.5 & 2.408 & 7.200 & 0.0018 \\
\hline T4 & 25.5 & 2.741 & 7.200 & 0.0016 \\
\hline T5 & 25.5 & 2.785 & 7.200 & 0.0020 \\
\hline ISEM & 0.264 & 0.138 & 0.0020 & 0.001 \\
\hline P-value & 1.00 & 0.155 & 1.00 & 0.746 \\
\hline \multicolumn{5}{|c|}{ The experiential months } \\
\hline Jule & 25.00 & 2.59 & 7.00 & 0.0010 \\
\hline August & 28.00 & 2.34 & 7.00 & 0.0010 \\
\hline September & 27.00 & 2.15 & 8.00 & 0.0018 \\
\hline October & 26.00 & 2.69 & 7.00 & 0.0023 \\
\hline November & 21.50 & 3.45 & 7.00 & 0.0030 \\
\hline ISEM & 0.264 & 0.135 & 0.0002 & 0.0001 \\
\hline P-value & 0.0001 & 0.0001 & 0.0001 & 0.0001 \\
\hline
\end{tabular}

The maximum growth rate (Table, 4 ) was obtained with the Nile tilapia groups (T1, T2, T3 and T4) fed on a diet containing $26.58 \% \mathrm{CP}$, as well as with fish groups reared with deferent levels of Silver carp (T2, T3 and T4). The means of growth performance traits (Table, 4) indicated that group 2 (96\% tilapia and $4 \%$ Silver carp) was higher significantly ( $\mathrm{P} \leq 0.05)$ than those of group 1 (100\% tilapia), group 3 (92\% tilapia and $8 \%$ Silver carp) and group 4 ( $88 \%$ tilapia and $12 \%$ Silver carp), respectively. The mean final body weight ranged between $84.13 \mathrm{~g}$ to $100.58 \mathrm{~g}$ among all treatments (Table 4). Significantly $(P \leq 0.05)$ the maximum average final body weight for both male Nile tilapia (100.58 g) and Silver carp(153.8 g) were recorded in T2 (96\% tilapia and $4 \%$ Silver carp). The growth performance for male Nile tilapia over the 124 experimental days, expressed as range means of ADG, RGR and SGR were significantly $(P \leq 0.05)$ increased, from a minimum to maximum to be $0.523 \mathrm{~g}-0.655 \mathrm{~g}, 335.9-421.1$ and $1.187 \%-1.331 \%$ day, respectively.

Jobling, (1993) reported that fluctuation food consumption and growth performance for fish may be related to many environmental factors (temperature, fish size, stocking density, access to acceptable quality of food, water exchange and salinity). The present results (Table, 4) confirmed with the previous explanations. Schmittom (2006) reported that the full utilization of little space from water using, may be give maximum fish production and improve the profitability of the fish farm, from through intensive culture. Thus, in the same direction Abdelhamid (2011) recommended on experiment basis carried out for 6 months in Manzala Lake on rearing Nile tilapia and Silver carp, whether under monoculture or polyculture at different stocking densities four floating net cages $(10 \times 10 \times 3 \mathrm{~m})$ were used. 
Growth performance of Silver carp is shown in (Table 4). Mean initial body weights for Silver carp in all stocking density treatments were $73.67 \mathrm{~g}$. The growth performance for fish represented by the averages of final weight, average weight gain, ADG (g), RGR and SGR were significantly affected by stocking density $(P \leq 0.05)$, (Table 4$)$. The growth performance for fish was reflected in positively increased of T2 compared to T3, T4 and T5

Table (4): Growth performance of Nile tilapia and Silver carp in floating net cages under different mono-and polyculture rearing and stocking rates systems:

\begin{tabular}{|c|c|c|c|c|c|c|}
\hline Cage & $\begin{array}{c}\text { Average initial } \\
\text { weight }(\mathrm{g})\end{array}$ & $\begin{array}{c}\text { Average } \\
\text { final weight } \\
\text { (q) }\end{array}$ & $\begin{array}{c}\text { Average } \\
\text { weight } \\
\text { gain (q) }\end{array}$ & ADG $(g)$ & RGR (\%) & $\begin{array}{c}\text { SGR } \\
\text { (\%/day) }\end{array}$ \\
\hline \multicolumn{7}{|c|}{ Growth performance parameters of Nile tilapia } \\
\hline TT1 & 19.30 & $84.13^{\mathrm{D}}$ & $64.83^{\mathrm{D}}$ & $0.523^{\mathrm{D}}$ & $335.9^{D}$ & $1.187^{\circ}$ \\
\hline T 2 & 19.30 & $100.58^{\mathrm{a}}$ & $81.28^{\mathrm{a}}$ & $0.655^{\mathrm{a}}$ & $421.1^{\mathrm{a}}$ & $1.331^{\mathrm{a}}$ \\
\hline T 3 & 19.30 & $96.67^{\mathrm{a}}$ & $77.36^{a}$ & $0.624^{\mathrm{a}}$ & $400.8^{a}$ & $1.298^{\mathrm{a}}$ \\
\hline T 4 & 19.30 & $97.46^{\mathrm{a}}$ & $78.16^{\mathrm{a}}$ & $0.630^{\mathrm{a}}$ & $405.0^{\mathrm{a}}$ & $1.305^{\mathrm{a}}$ \\
\hline \pm SEM & 0.000 & 1.236 & 1.232 & 0.0100 & 6.382 & 0.010 \\
\hline P-value & 1.00 & 0.0001 & 0.0001 & 0.0001 & 0.0001 & 0.0001 \\
\hline \multicolumn{7}{|c|}{ Growth performance parameters of Silver carp } \\
\hline$T 2$ & 73.67 & $227.5^{\mathrm{a}}$ & $153.8^{\mathrm{a}}$ & $1.240^{\mathrm{a}}$ & $208.8^{a}$ & $0.90^{\mathrm{a}}$ \\
\hline T 3 & 73.67 & $219.2^{\mathrm{ab}}$ & $145.5^{\mathrm{ab}}$ & $1.173^{\mathrm{ab}}$ & $197.6^{\mathrm{ab}}$ & $0.87^{\mathrm{ab}}$ \\
\hline TT 4 & 73.67 & $179.5^{\mathrm{C}}$ & $105.8^{\mathrm{C}}$ & $0.853^{\mathrm{C}}$ & $143.7^{\mathrm{C}}$ & $0.71^{\mathrm{C}}$ \\
\hline T 5 & 73.67 & $196.7^{\mathrm{bc}}$ & $123.0^{\mathrm{bc}}$ & $0.992^{\mathrm{bc}}$ & $167.0^{\mathrm{bc}}$ & $0.78^{\mathrm{bc}}$ \\
\hline ESEM & 0.000 & 9.44 & 9.44 & 0.076 & 12.81 & 0.037 \\
\hline$P$-value & 1.00 & 0.014 & 0.014 & 0.014 & 0.014 & 0.123 \\
\hline
\end{tabular}

Means in the same column having different letters significantly different $(P \leq 0.05)$.

The growth rates for Silver carp, over the 124 experimental days, expressed as means of ADG, RGR and SGR, were significantly ( $P \leq 0.05)$ ranged, from $1.240 \mathrm{~g}-0.853 \mathrm{~g}, 208.8 \%-143.7 \%$ and $0.90 \% /-0.71 \% /$ day, respectively, Table (4).

Table (5) the compression between Nile tilapia and Silver carp for growth performance. Nile tilapia was better than Silver carp in relative growth rate and specific growth rate. The differences between two species were highly significant $(\mathrm{P} \leq 0.05)$. The same results was recorded by Abuo-sief et al., (2012) that growth performance of different fish species, mean individual growth rate was highest for lower density and it was lowest for the higher density of each species with significant difference $(P \leq 0.05)$.

Table (5): Comparison of growth performance between Nile tilapia and Silver carp in monoculture system:

\begin{tabular}{|l|c|c|c|c|c|}
\hline Cage & $\begin{array}{c}\text { Average Final } \\
\text { weight } \mathbf{( g )}\end{array}$ & $\begin{array}{c}\text { Average weight } \\
\text { gain } \mathbf{( g )}\end{array}$ & ADG (g) & RGR (g) & SGR (g) \\
\hline Nile tilapia & $84.13^{\mathrm{a}}$ & $64.83^{\mathrm{a}}$ & $0.523^{\mathrm{a}}$ & $335.9^{\mathrm{a}}$ & $1.187^{\mathrm{a}}$ \\
\hline Silver carp & $196.7^{\mathrm{b}}$ & $123.0^{\mathrm{b}}$ & $0.992^{\mathrm{b}}$ & $167.0^{\mathrm{b}}$ & $0.78^{\mathrm{b}}$ \\
\hline ISEM & 10.59 & 10.59 & 0.085 & 14.98 & 0.042 \\
\hline P-value & 0.0002 & 0.0039 & 0.0039 & 0.0003 & 0.001 \\
\hline
\end{tabular}

Means in the same column having different letters significantly different (P $\leq 0.05)$. 
These values are non-agreement with those reported by Bakeer (2001) who found that final body weight of Silver crap increased significantly $(P \leq 0.05)$ with lower stocking density, daily gain $(\mathrm{g})$ was between 2.49 and 3.629 , specific growth rate (SGR) between 2.67 to 2.82 and total fish yields of Silver crap were 1277.95 and $2482.44 \mathrm{~kg} /$ cage when the their stocking rate was 2500 and 5000 fish /cage under the some condition and the site of cages.

Table (6) shows that feed conversion ratio and feed utilization were highly significant affected by stocking density $(P \leq 0.05)$. Feed intake and protein productive value was the high significantly $(P \leq 0.05)$ in T3 and T2 than that recorded in $\mathrm{T} 1$ and $\mathrm{T} 4$. The feed conversion ratio was significantly $(P \leq 0.05)$ differed between groups. The values 2.61 in T1 group were decreased in T2, T3 and T4 by addition Silver carp fish in the cages.

Feed intake (FI), protein efficiency ratio (PER), protein productive value (PPV) and energy utilization (EU) were increased significantly $(P \leq 0.05)$ in the cages containing Silver carp, also protein efficiency ratio improved significantly $(P \leq 0.05)$ in T2 compared with T1, T3 and T4 and energy utilization was the high significantly $(P \leq 0.05)$ in T2, T3 and T4 than that recorded in T1 (Table 6).

Nearly similar results were found by Asase (2013) who found that the FCR of Nile tilapia fingerlings (2.12) were significantly affected by stocking densities $(P \leq 0.05)$.

Table (6): The effects of different stocking density on feed intake and nutrients utilization of treatments at the end of the experiment:

\begin{tabular}{|l|c|c|c|c|c|}
\hline Treatment & FI & FCR & PER & PPV & EU \\
\hline$T 1$ & $168.9^{\mathrm{C}}$ & $2.61^{\mathrm{a}}$ & $1.59^{\mathrm{C}}$ & $21.48^{\mathrm{c}}$ & $11.97^{\mathrm{b}}$ \\
\hline $\mathrm{T} 2$ & $174.1^{\mathrm{ab}}$ & $2.14^{\mathrm{c}}$ & $1.94^{\mathrm{a}}$ & $24.06^{\mathrm{ab}}$ & $15.70^{\mathrm{a}}$ \\
\hline $\mathrm{T} 3$ & $177.2^{\mathrm{a}}$ & $2.29^{\mathrm{b}}$ & $1.81^{\mathrm{b}}$ & $25.83^{\mathrm{a}}$ & $15.83^{\mathrm{a}}$ \\
\hline $\mathrm{T} 4$ & $172.3^{\mathrm{bC}}$ & $2.20^{\mathrm{bC}}$ & $1.88^{\mathrm{ab}}$ & $23.91^{\mathrm{b}}$ & $15.32^{\mathrm{a}}$ \\
\hline ISEM & 1.405 & 0.040 & 0.030 & 0.576 & 0.346 \\
\hline P-value & 0.009 & 0.0001 & 0.0001 & 0.0016 & 0.0001 \\
\hline
\end{tabular}

Means in the same column having different letters significantly different $(P \leq 0.05)$.

Table (7) shows that carcass composition of Nile tilapia in cages 1, 2, 3 and 4. The values of dry matter (DM), crude protein (CP), ether extract (EE), energy content (EC) and ash of the experimental samples of the cages were significantly different $(P \leq 0.05)$ between treatments. Treat. 2 gave the high values of EE and EC compared with that of Treat 1, 3 and 4, respectively. The CP and ash of Nile tilapia at the start the experiment was higher than other traits at the end of the experiment. 
Table (7): Carcass chemical composition of Nile tilapia and Silver carp groups at the start and at the end of the experiment.

\begin{tabular}{|l|c|c|c|c|c|}
\hline Treatment /Variables. & DM & CP & EE & EC & Ash \\
\hline \multicolumn{5}{|c|}{ Nile tilapia: } \\
\hline At the start: & 20.86 & 59.47 & 13.61 & 463.88 & 26.92 \\
\hline At the end: & $22.72^{\mathrm{b}}$ & $58.19^{\mathrm{a}}$ & $21.54^{\mathrm{d}}$ & $531.6^{\mathrm{c}}$ & $20.26^{\mathrm{a}}$ \\
\hline T1 & $22.27^{\mathrm{b}}$ & $55.64^{\mathrm{c}}$ & $28.55^{\mathrm{a}}$ & $583.4^{\mathrm{a}}$ & $15.80^{\mathrm{b}}$ \\
\hline T2 & $24.30^{\mathrm{a}}$ & $57.04^{\mathrm{b}}$ & $26.19^{\mathrm{C}}$ & $569.0^{\mathrm{b}}$ & $16.76^{\mathrm{b}}$ \\
\hline T3 & $22.74^{\mathrm{b}}$ & $55.50^{\mathrm{C}}$ & $27.49^{\mathrm{b}}$ & $572.6^{\mathrm{b}}$ & $17.00^{\mathrm{D}}$ \\
\hline T4 & 0.405 & 0.306 & 0.188 & 2.483 & 0.358 \\
\hline ISEM & 0.033 & 0.0008 & 0.0001 & 0.0001 & 0.0001 \\
\hline P-value & 19.49 & 68.20 & 9.75 & 476.68 & 22.05 \\
\hline \multicolumn{7}{|l|}{} \\
\hline At the start: & $16.09 \mathrm{ab}$ & $70.33 \mathrm{a}$ & $7.730 \mathrm{~b}$ & $469.6 \mathrm{a}$ & $21.94 \mathrm{c}$ \\
\hline At the end: & $17.23 \mathrm{a}$ & $67.31 \mathrm{c}$ & $7.403 \mathrm{~b}$ & $449.5 \mathrm{c}$ & $25.28 \mathrm{a}$ \\
\hline T2 & $15.64 \mathrm{~b}$ & $68.47 \mathrm{bc}$ & $7.450 \mathrm{~b}$ & $456.5 \mathrm{~b}$ & $24.08 \mathrm{~b}$ \\
\hline T3 & $17.01 \mathrm{a}$ & $69.65 \mathrm{ab}$ & $8.733 \mathrm{a}$ & 476.68 & 22.05 \\
\hline T4 & 0.365 & 0.434 & 0.231 & 0.334 & 1.951 \\
\hline T5 & 0.0451 & 0.0054 & 0.0117 & 0.0001 & $<.0001$ \\
\hline ISEM
\end{tabular}

Means in the same column having different letters significantly different $(P \leq 0.05)$.

Table (7) shows that carcass chemical composition of Silver carp in Treat 2, 3, 4 and 5. The mean values of dry matter, crude protein, ether extract, energy content and ash of the examined samples were significantly different $(P \leq 0.05)$. The carcass samples of Treat. 2 at the end experiment showed high values of $\mathrm{CP}, \mathrm{EE}$ and EC, but it was less in DM and ash compared to the treatments 3 and 4, respectively. Carcass traits of Silver carp were highest in DM, EE and EC at the start of the experiment than at the end experiment.

The carcass composition of Nile tilapia was the center point in several studies from different side of views. In this respect, it was found from the proximate chemical analysis of Nile tilapia whole body including total lipids and total ash was significantly influenced by dietary protein level only (AbdelTawwab, 2012). On the other hand, changes in protein rate in their synthesis, deposition rate in muscle and/or different growth rate (Abdel-tawwab et al., 2006). In additionally, khalil et al., (2012) suggested that fish carcass composition in both male and female of Nile tilapia were took unclear trends between adult males and female within all treatments. Generally, there is a negative relationship between $\mathrm{CP}$ and crude fats in the chemical composition of Nile tilapia carcass. As well as, khalil et al., (2011) shows that carcass composition of tilapia species in cages site, whose DM, CP, EE and EC were significantly different $(P \leq 0.01)$. while, ash increased significant in Nile tilapia among other tilapia species, as well as, khalil et al., (2015) reported that fish reared at high stocking density had significantly $(P \leq 0.05)$ increased DM, EE and EC, while ash and CP were significantly decreased comported to the low stocking density rate. The previous results are in more or less help in explaining the present obtained finding. 


\section{Economic efficiency and conclusions}

Table (8) shows the economic efficiency of Nile tilapia and Silver carp rearing of mono and polyculture under different stocking rates in floating net cages in Manzala Lake, Egypt. The results indicated that the total output, net return and economic efficiency as percentage were gradually increased with the increasing levels of Silver carp in cages 2, 3 and 4, respectively. Whereas, the economical efficiency EF\% was less in cage 1 of tilapia $(39.59 \%)$ than in cage 5 of Silver carp $(200 \%)$ for monoculture system. It is important to monition that Silver carp in cage 5 fed on natural food in water only. This mean that no cost of feeding. Therefore, the total profit shows the best value in cage 5 in relation to all other cages. In the same time, the cages 2, 3 and 4 shows the same trend of total profit related to the stocking rates of Silver carp in the cages. The results indicated that the best stocking rate between tilapia and Silver carp of economic efficiency was $88 \%$ tilapia and $12 \%$ Silver carp.

Table (8): Illustrates input, output and economic efficiency per cage on the basis of the footnote equations:

\begin{tabular}{|l|c|c|c|c|}
\hline Cage & $\begin{array}{c}\text { Total input } \\
\text { of cage (LE) }\end{array}$ & $\begin{array}{c}\text { Total output } \\
\text { of cage (LE) }\end{array}$ & $\begin{array}{c}\text { Total profit of } \\
\text { cage (LE) }\end{array}$ & $\begin{array}{c}\text { Economic } \\
\text { efficiency } \%\end{array}$ \\
\hline T1 & 4450 & 6210 & 1760 & 39.59 \\
\hline T2 & 4600 & 7310 & 2710 & 58.98 \\
\hline T3 & 4715 & 7680 & 2965 & 60.95 \\
\hline T4 & 4680 & 7980 & 3300 & 70.47 \\
\hline T5 & 1200 & 3600 & 2400 & 200 \\
\hline
\end{tabular}

Total feed costs per treatment (cage) $\left(\right.$ LE $/ \mathrm{Kg}$ diet) $=$ feed costs per one $\mathbf{k g}^{\star *}$ diet $\mathrm{X}$ feed intake.

Total outputs per treatment (cage) $(\mathrm{LE} / \mathrm{Kg})=$ fish price $X$ total fish production ${ }^{\star \star *}$.

Net return per cage $(L E)=$ total outputs - total inputs.

Economic efficiency per cage $(\%)=($ net return $/$ total feed costs) $X 100$.

*Economic efficiency (return $\times 100 /$ total input/cage), feed cost/ $\mathrm{Kg}$ diet according to the local prices year 2013 for fish and feed, where 1 US dollar $=7.50$ L.E.

${ }^{* *}$ The price of $1 \mathrm{~kg}$ diet used in the present study was (3.20) LE at Egypt (2013).

*** Total fish production per treatment (cage) $=$ final number of fish $\mathbf{X}$ fish weight gain.

The same results were recorded by many researches, such as Asase (2013) they recommended that Nile tilapia fingerlings stocked in cages at densities of 50 fish $1 \mathrm{~m}^{3}, 100$ fish $1 \mathrm{~m}^{3}$ and 150 fish $1 \mathrm{~m}^{3}$, The economic feasibility, profit index were not significant $(p \leq 0.05)$ between the 100 fish $1 \mathrm{~m}^{3}$ and 150 fish $1 \mathrm{~m}^{3}$ treatment. The production, net yield and gross profits showed significant $(p \leq 0.05)$ increase with higher stocking densities. Meanwhile, Beveridge (2004) reported that feed cost is usually the highest variable cost averaging around 50 to $60 \%$ of total cost. The second highest variable cost is usually seed or fingerlings costs and can range from 10 to $40 \%$ of variable cost. While, watanabe et al., (1990) reported appositive relationship between stocking density have also been reported be Alemu (2003) and Gibtan et al., (2008) for Nile tilapia.

In the same trend, Abdelhamid (2011) recommended that as experiment was carried on rearing Nile tilapia and Silver carp, whether under 
monoculture or polyculture at different stocking densities, four flouting net cages. Feed cost $1 \mathrm{~kg}$ body weight gain (7.78 \& 5.89 L.E.) and economic efficiency (144.5\& $77.9 \%$ ), respectively. Moreover, the monoculture of all males mono-sex Nile tilapia was also the best treatment in return followed by polyculture treatment. Whereas, Abuo-sief et al., (2012) found that the best species combination (crop composition) ratios in polyculture system was $(60 \%$ tilapia $+10 \%$ common carp $+10 \%$ silver carp +20 catfish $)$ which recorded the highest fish production and net profit. Also, Mandel et al., (2012) found cage-pond integration system of and Nile tilapia with carps is the best technology to increase production, where as integration of tilapia and carp for profitability.

The present obtained results lead to the importance using the balanced pelleted complete diet for feeding tilapia fish especially under intensive cultured (monoculture); as well as, depending of green water for fed Silver carp in intensive monoculture. Also, showed the superiority of stocking densities in polyculture system were $88 \%$ and $12 \%$ for Nile tilapia and Silver carp, respectively under Manazala Lake environment.

\section{REFERENCES}

Abdelhamid, A.M. (2003). Scientific Fundamentals for Fish Production and Management, 2nd Rev. Ed., Deposit No. 15733/2003, Man. Univ., Press.

Abdelhamid, A.M. (2011). Intensive Rearing of Mono-Sex Nile Tilapia and Silver carp under mono or polyculture systems at different stocking densities in floating net cages. J. Animal and Poultry Production, Mansoura Univ., Vol.2 (7): 277-289.

Abdelhamid, A.M.; Ibrahim, M.A. Maghraby, N.A. and Soliman, A.A.A. (2007). Effect of dietary supplemented of betaine and/or stocking density on performance of Nile tilapia. J. Agric. Sci. Man., Univ., 32: 167-179.

Abdel-Tawwab, M. (2012). Interactive effects of dietary protein and live bakery yeast, Saccharamyces cerevisiae on growth performance of Nile tilapia, Oreochomis nilotcus (L.) fry and their challenge against Aeromonas hydrophila infection. Aquacult Int., 20: 317-331.

Abdel-Tawwab, M.;Hany, El-Marakby, H. I. and Ahmad, M. H. (2006). Cannibalism in Oreochromis niloticus effect of stocking density, feed quality and submerged macrophytes. Indian J. Fish., 53(3): 245-251.

Abuo-sief, R. A.; Radwan, M. E. I. and Mahmoud, A. A. (2012). Effect of Crop Stocking Ratios of Nile Tilapia, Common Carp, Silver Carp and Catfish in Polyculture in Concrete Ponds with $10 \mathrm{~cm}$ Clayey Loam on Growth Performance and Total Yield. Journal of The Arabian Aquaculture Society Vol. 7 No 1.

Aldwaney, S.H. (2002). Short cut on aquaculture in Damro sector - Kafr ElSheikh. Forum of the real, inspections and how to reach the aimed in our fish production. Al-Mansoura, 11 Feb., pp: 43 - 59.

Alemu, K. (2003). The growth performance of Oreochromis niloticus reared in freshwater ponds loaded with varying levels of poultry manure. SINET: Ethiopia Journal of Science, 26: 17-23. 
AOAC, (2000). Association of Official Analytical Chemists of Official Methods of Analysis. 17th Ed., Washington, DC.

APHA, (1971). American Public Health Association, Standard methods for examination of water and waste water. Washington, DC, $874 \mathrm{pp}$.

APHA, (1992).American Public Health Association, Standard methods for examination of water and waste water. $18^{\text {th }}$ edition. Washington, DC.

Asase, A. (2013). Effects Of Stocking Density On The Production Of Nile Tilapia (Oreochromis Niloticus) In Floating Net Cages On The Volta Lake. In Partial Fulfilment Of The Requirement For The Award Of Mphil Fisheries Science Degree, A Thesis Submitted To The University Of Ghana, Legon.

Bakeer, M. N. (2001). Growth responses of sliver carp (Hypophthalmichthys molirtrix ) cultured in cages to manuring at different stocking densities .Annals of Agric .Sc.,Moshtohor , 39(3):1517-1529.

Bakeer, M.N.; Mostafa, M.A.A. and Higaze, A.Z. (2007). Effect of fish size and density at initial stocking on growth performance and fish marketable size. J. Agric. Sci. Mansoura Univ., 32: 1803-1813. (ISSN: 1110-0346).

Beveridge, M. (2004). Cage aquaculture (3rd edition). Wiley-Blackwell Publishing, Oxford, UK. 380 pp.

Degefu, F.; Mengistu, S. and Schagerl, s. (2011). Influence of fish cage farming on water quality and plankton in fish ponds: A case study in the Rift Valley and North Shoa reservoirs, Ethiopia. Aquaculture, 316: 129135.

Diana, J.S.;Yi, Y. and Lin, C. K. (2004). Stoking densities and fertilization regimes for Nile tilapia (Oreochromis niloticus) production in ponds with supplemental feeding. Proceedings of $6^{\text {th }}$ International Symposium on Tilapia in Aquaculture, Roxas Boulevard, Manila, Philippines, pp. 487499. (http://ag.arizona.edu/azaqua/ista/ista6/Abstracts6.htm).

Duncan, D.B. (1955). Multiple range and multiple F-test. Biometrics, 11:1-42.

El-Ganainy, A.A. (2006). The Enhancement of The. Role of Women in The Artisanal Fishing Communities to Help in Improving The Livelihood of Their Families. Women/Youth and the Sea Program 2006, IOIProject,pp:12.

Ellis, T.; North, B.; Scaott, A.P.; Bromage, N.R.; Porter, M. and Gadd, D. (2002). The relationships between stocking density and welfare in farmed rainbow trout. Journal of Fish Biology, 61: 493-531.

El-Sayed, A.F.M. (2006). Tilapia Culture. CABI Publishing, UK.

El-Sayed, A.F.M. (2013). On-farm feed management practices for Nile tilapia in Egypt. In M.R. Hassan and M.B. New, Eds. On-farm feeding and feed management in aqua., FAO Fisheries and Aquaculture Technical Paper No. 583. Rome, FAO. pp. 101-129.

FAO, Food and Agriculture Organization (2005). Fish stat Plus, version 2.30. Food and Agriculture Organization of the United Nations, Rome, Italy.

GAFRD, (2006). The General Authority for Fish Resources Development yearbook, "Statistics of Fish Production", Ministry of Agriculture and Land Reclamation, Cairo, Egypt. Updated 1990, Cited 2006. 
GAFRD, (2008). The General Authority for Fish Resources Development yearbook, "Statistics of Fish Production, Cairo, Egypt.

Gibtan, A.; Getahun, A. \& Mengistou, S. (2008). Effect of stocking density on the growth performance and yield of Nile tilapia (Oreochromis niloticus L., 1758) in a cage culture system in Lake Kuriftu, Ethiopia. Aquaculture Research, 39: 1450-1460.

Jobling, M. (1993). Bioenergetics: feed intake and energy partitioning. In: Rankin J.C., Jensen F., editors. Fish Ecophysiology. London: Chapman \& Hall; p.1-44.

Khalil, F. F.; Mehrim, A. I.; El-Shebly, A. A. and Abdelaal, Mm. e. (2011). An Assessment Study of Tilapia Polyculture in Floating Net Cages. J. Animal and Poultry Production, Mansoura Univ., Vol. 2 (5): 75 - 92.

Khalil, F. F.; Mehrim A. I. and Hassan, M. E. (2012). Effect of Hydroyeast Aquaculture as growth promoter for adult Nile tilapia Oreochromis niloticus. J. Animal and Poultry Pord., Mansoura Univ., 3(6): 305-317.

Khalil, F. F.; Mehrim, A. I. and Abdalqadir, A. M. (2015).Dietary pro-Grow probiotic against high stoking density stress: 1- Effect on water quality, growth performance, feed utilization and carcass composition of Nile tilapia Oreochromis niloticus. J. Animal and Poultry Prod., Mansoura Univ., 7 (5): 377 - 395.

Khattab, Y.A.E.; Mohsen, A. and Ahmed, M.H. (2004). Effect of protein level and stocking density on growth performance, survival rate, feed utilization and body composition of Nile tilapia fry Proceedings of $6^{\text {th }}$ International Symposium on Tilapia in Aquaculture, Roxas Boulevard, Manila, Philippines, pp. 264-276.

Macdonald, P.; Edwards, R.A. and Greenhalgh, J.F.D. (1973). Animal Nutrition, $2^{\text {nd }}$ Ed., Longman, London.

Mandal, R. B.; Jha, D. K.; Shrestha, M. K.; Pant, J.; Rai, S. and Pandit, N. P. (2012). Cage-pond integration of African catfish (Clarias gariepinus) and Nile tilapia (Oreochromis niloticus) with carps. Aquac. Research, 1-8.

SAS, (2006). SAS / STAS Guide for personal computer SAS Institute Inc., Cary, NC, USA.

Schmittou, H.R.(2006). Cage Culture. In C. Lim \& C. Webster (Eds), Tilapia Biology, Culture, and Nutrition (pp. 181-210). Food Products Press, New York. 678pp.

Watanabe, W.; Clark, J.; Dunham, J.; Wicklund, R. \& Olla, B. (1990). Culture of Florida red tilapia in marine cages: effect of stocking density and dietary protein on growth. Aquaculture, 90: 123-134. 


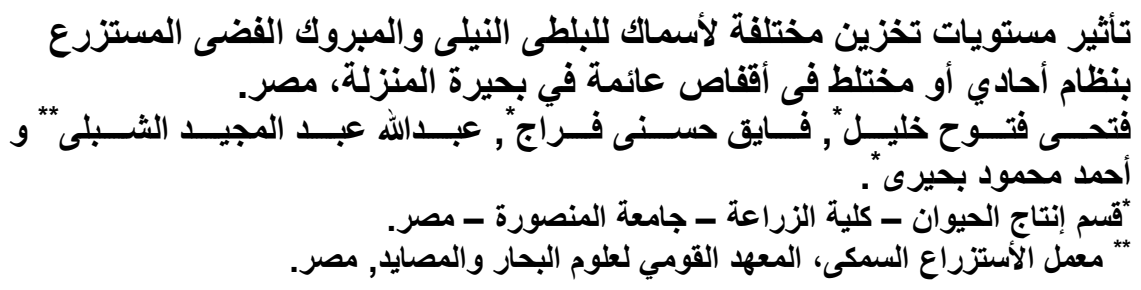

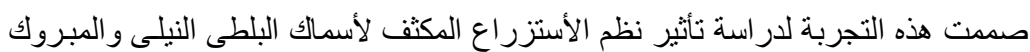

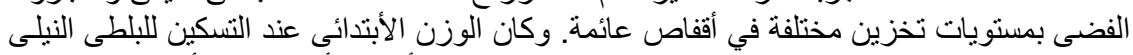

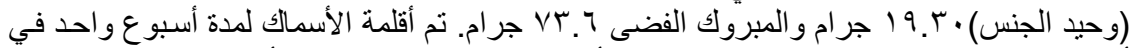

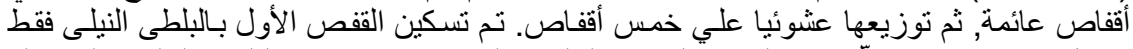

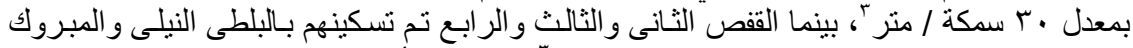

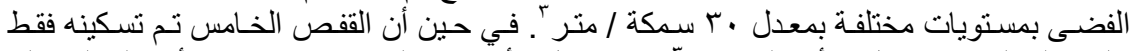

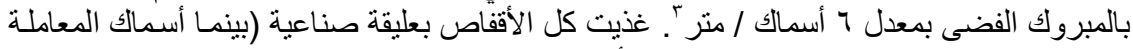

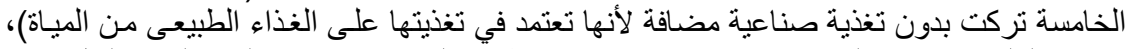

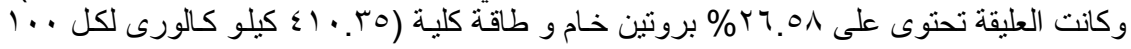

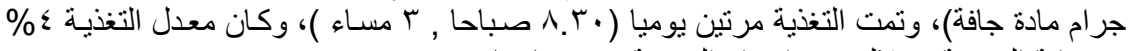

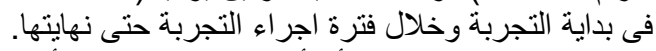

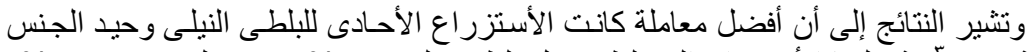

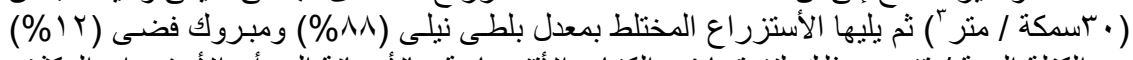

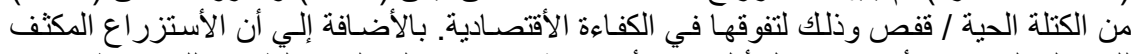

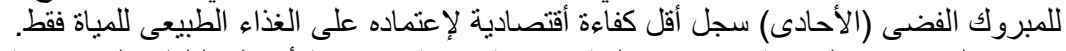

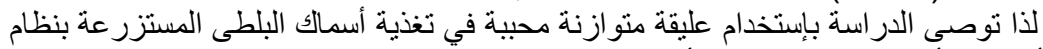

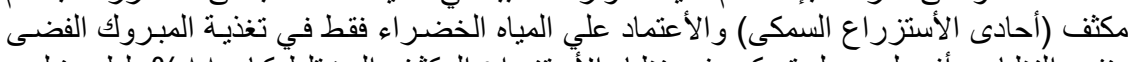

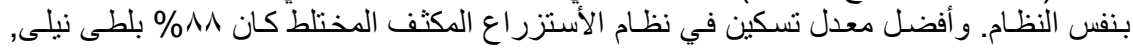

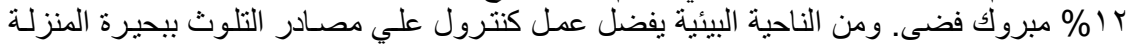

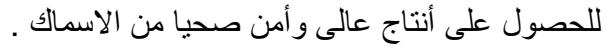

